\title{
A construção da escuta-flânerie: uma pesquisa psicanalítica com socioeducadores
}

\author{
Luísa Puricelli Pires* (1) \\ Rose Gurski 10
}

Universidade Federal do Rio Grade do Sul, Instituto de Psicologia. Porto Alegre, RS, Brasil

\begin{abstract}
Resumo: A partir de rodas de conversa com adolescentes acautelados em uma instituição socioeducativa, desenvolvidas pelo Núcleo de Pesquisa no qual esta investigação está inserida, decidimos ampliar os espaços de escuta aos agentes socioeducadores. A apresentação massiva de real, por meio da estética do lugar, das cenas presenciadas na instituição e de algumas narrativas dos agentes, foi sendo engendrada a partir de dois pressupostos teóricos: a escuta psicanalítica e a leitura benjaminiana da posição do flâneur de Baudelaire. O flâneur, como aquele que imprime um tempo distendido à urgência, foi tomado como o correspondente corporal para a atenção flutuante. Nesse sentido, a psicanálise e a flânerie conjugaram-se a fim de abrir espaços de narração por meio dos quais os sujeitos podiam retomar pontos extraviados da história social e da sua própria. O escrito apresenta a escuta-flânerie como um modo de a escuta e a pesquisa psicanalítica estarem presentes também nesses sítios.
\end{abstract}

Palavras-chave: pesquisa psicanalítica, agentes socioeducadores, socioeducação, escuta-flânerie.

Em nossos dias, temos deparado com discursos de ódio e atuações sociais abusivas com relação aos direitos humanos, sendo uma de suas principais marcas a recusa das diferenças. Tomamos esses como sinais de tempos sombrios, semelhantes àqueles em que Hannah Arendt e Walter Benjamin estavam imersos, ao longo da década de 1930, no momento do entreguerras. As mais diversas manifestações de violência que temos presenciado nos colocam a refletir acerca de um empobrecimento dos pilares que sustentam o laço social; nas palavras de Arendt (1955/1987), “a própria humanidade do homem perde sua vitalidade na medida em que ele se abstém de pensar e deposita sua confiança em velhas ou mesmo novas verdades, lançando-as como se fossem moedas com que se avaliassem todas as experiências" (p. 19). Tal configuração parece revelar que a pobreza metafórica de nosso tempo, associada a uma dose intensa de certezas, muitas vezes, atrelada à busca dos prazeres efêmeros, nos aparta de um tempo distendido, assim como da possibilidade de pensar (Benjamin, 1933/2012).

Nesse cenário tem sido uma preocupação intervir no laço social desde a ética da psicanálise, o que nos lança às interrogações sobre como construir maneiras de a escuta psicanalítica estar presente em espaços fora da clínica-padrão. A história do grupo de pesquisa ${ }^{1}$ ao qual

* Endereço para correspondência: luisa_puricelli@yahoo.com.br

1 Referimo-nos aqui ao eixo de pesquisa "Psicanálise, educação, adolescência e socioeducação", que faz parte do Núcleo de Pesquisa em Psicanálise, Educação e Cultura (Nuppec-UFRGS). O Núcleo é uma ação conjunta do Programa de Pós-Graduação (PPG) em Psicanálise: Clínica e Cultura e do PPG em Educação, reunindo professores, mestrandos, doutorandos, pesquisadores associados e bolsistas. Para mais informações, acesse www.ufrgs.br/nuppec e www.facebook.com/nuppec. este estudo ${ }^{2}$ está vinculado é permeada por trabalhos que acontecem em condições precárias, marcadas por uma cultura e temporalidade específicas, em que os sujeitos estão "saciados e exaustos" (Benjamin, 1933/2012, p. 127) de vivências. A voracidade pela busca de informações, aguçada pelas virtualidades do século XXI, deixa de lado um tempo de contemplação e compartilhamento. Pobres em experiências (Erfahrung), o excesso de vivências (Erlebnis) pode até mesmo impedir a criação e a narração das histórias e acontecimentos vividos.

$\mathrm{O}$ trabalho que apresentamos neste artigo teve início nos estudos que o grupo vem desenvolvendo acerca da produção social da violência juvenil e, nos últimos anos, mais especificamente sobre a intervenção em uma instituição socioeducativa. As investigações que vêm sendo desenvolvidas com a socioeducação iniciaram pela via da apresentação de um projeto de pesquisaintervenção ${ }^{3}$ que propunha um espaço de escuta com grupos de adolescentes que aguardavam decisão judicial ou cumpriam medida socioeducativa em meio fechado. Nesse processo foi ganhando força a conjugação de um paralelo entre a potência da palavra para a psicanálise $\mathrm{e}$ os efeitos do tema da experiência em Walter Benjamin (1933/2012); desde o início, essa conjugação sublinha a noção de que a narração e o compartilhamento das

2 Este artigo é derivado da pesquisa de mestrado intitulada A construção da escuta-flânerie: uma pesquisa psicanalítica com agentes socioeducadores que atendem adolescentes em conflito com a lei (Pires, 2018a).

3 Em 2014, propôs-se à instituição o projeto de pesquisa "Os jovens em conflito com a lei, a violência e o laço social", que teve o apoio do Conselho Nacional de Desenvolvimento Científico e Tecnológico (CNPq), pelo Edital Universal. 
vivências fomentam experiências que desacomodam e enriquecem os sujeitos (Gurski, 2012; Gurski \& Strzykalski, 2018).

Enlaçamos à posição ética do psicanalista e à escuta da transferência o tema da experiência e a figura do flâneur em Benjamin. Por meio de sua tese de doutorado, Gurski (2008) situava um ponto de referência para essa ideia de fazer conversar a psicanálise, o tema da experiência em Walter Benjamin e a flânerie retomada de Baudelaire por Benjamin, construindo a noção de ensaio-flânerie, fazendo daí decantar um método de investigação e de escrita. Dali em diante, outros efeitos foram produzidos nos diferentes trabalhos do grupo, como a nomeação da posição do catador de restos na escuta de jovens das margens (Gurski \& Strzykalski, 2018).

A inspiração na flânerie se aloca no modo de pesquisar que se dá a contrapelo do ritmo imposto pela nossa sociedade, à medida que permite uma "liberdade poética" do pensar, possibilitando-nos "desenvolver todo um modo investigativo de refletir sobre certas nuances do laço social" (Gurski, 2014, p. 172). Apresentando uma forma de olharmos para a educação como potência, Gurski sublinhou a dinâmica do inconsciente, que está sempre pronto a comparecer para aquele que desejar presenciar suas aparições.

Aproximando-nos, inicialmente, das falas dos socioeducandos, os bolsistas de iniciação científica que acompanhavam as rodas de conversa e deparavam, em muitos momentos, com um real ${ }^{4}$ quase impossível de suportar. Eram descrições difíceis de escutar que continham detalhes dos delitos cometidos e retratavam a intensa vulnerabilidade social vivida por esses jovens. Por outro lado, essas vivências fraturadas - que sabemos ser uma dura realidade à qual grande parte da população brasileira está submetida - traziam questões recheadas de simbolismos, construções inusitadas e certa valorização do espaço de escuta que estava sendo oferecido.

Durante o percurso do grupo de pesquisa com os adolescentes surgiu a ideia de também abrir um espaço de escuta para os socioeducadores. A crueldade dos agentes, narrada pelos adolescentes e reproduzida, em supervisão, na fala das bolsistas, despertou uma inquietação: o que tal hostilidade poderia estar revelando ou mesmo escondendo a respeito do sofrimento dos agentes socioeducadores?

Foi a partir dessa problematização que surgiu a pesquisa de mestrado. Esta iniciou com a realização de entrevistas por meio das quais os socioeducadores eram escutados, dando sequência a uma metodologia de trabalho que propunha outras intervenções para a demandas da instituição. Ainda que nos locais repetidamente produzam-se discursos marcados pela demanda de que

4 O real se refere àquilo que é impossível de ser simbolizado e tem força inesgotável. Muito próximo do conceito de pulsão, o real em Lacan (1959-1960/2010) se refere ao que não cessa de não se inscrever e se presentifica como motor da angústia e daquilo que mais diz sobre o sujeito, embora não encontre palavras para dizer. É o que se apresenta em ato, é a própria coisa, Das Ding. É o mote do trabalho do psicanalista. alguém dê o caminho, insistimos na noção de que o sujeito tem um saber ${ }^{5}$ e que este pode emergir quando escutado.

\section{Algumas nuances da história social da socioeducação}

Retomando a história para pensar o contexto da socioeducação no Brasil, vemos que ela se enlaça com o passado marcado por uma lógica de colonização e escravidão, passando por um regime ditatorial por meio do qual revigoraram-se as vivências de exclusão da população negra e pobre em detrimento da figura do "homem intelectual branco". Nesse contexto, inúmeros autores salientam como se evidencia um público-alvo na socioeducação que abarca, em sua avassaladora maioria, os meninos negros ${ }^{6}$ da periferia. Para além da questão da cor da pele, é estranho pensar que uma sociedade centrada na figura masculina e que enaltece a juventude enquanto ideal vem matando esses jovens de forma drástica, sendo que mais da metade dos assassinatos que ocorrem no Brasil são de jovens entre 15 e 29 anos (Vidal et al., 2015).

A partir da Constituição de 1988, asseverou-se, dentre tantas prerrogativas, que a família, a sociedade $\mathrm{e}$ o Estado são responsáveis por manter os direitos básicos de crianças e adolescentes, tendo em vista que estes estão à época de constituir as bases de suas estruturas emocionais, intelectuais, físicas e sociais, necessitando de maiores cuidados. A partir do paradigma da execução da doutrina de proteção integral proposto pela Constituição, o Estatuto da Criança e do Adolescente - ECA (Brasil, 2015) aprofundou as questões a respeito do desenvolvimento da criança e do adolescente, apontando para o fato de que as punições físicas de menores acautelados deveriam ser proibidas, acrescentando a educação à função de segurança do monitor. Dezesseis anos depois, o governo, juntamente com representantes de entidades e especialistas, formulou o Sistema Nacional de Atendimento Socioeducativo Sinase (Brasil, 2006), que foi criado com a função de destacar aspectos relevantes à violência praticada e sofrida por adolescentes, regulando a atuação dos trabalhadores que atendem jovens em conflito com a lei. Esse documento teve uma espécie de continuidade quando se produziu o Programa de Execução de Medidas Socioeducativas de Internação e Semiliberdade do Rio Grande do Sul Pemseis (Brasil, 2014), o qual buscou oferecer diretrizes pedagógicas para a reintegração social desses jovens nas especificidades do atendimento socioeducativo do Estado.

5 Saber, aqui, diz respeito à verdade do sujeito do inconsciente: aquilo que se constitui a partir das experiências do sujeito e que pode ser acessado por meio de sua fala.

6 O local onde se deu a escuta-flânerie acolhe apenas adolescentes do sexo masculino, como ocorre na maioria das instituições socioeducativas do Brasil. Em nosso estado, as meninas somam, em média, 2,08\% dos adolescentes apreendidos pela polícia, enquanto um menino tem 47,07 vezes mais chance de ser preso e um menino negro tem probabilidade 3,38 vezes maior de cumprir medida socioeducativa comparando-se a um rapaz branco (Fundação de Atendimento Socioeducativo do Rio Grande do Sul, 2015). 
Permanecendo ainda hoje as feridas de uma instituição que nasce embasada nas premissas do sistema jurídico penal que busca acautelar e punir, durante nossa pesquisa vimos a rotina dos agentes convergindo para o provimento dos cuidados básicos de higiene e alimentação, acrescido da preocupação com a segurança. Esse paradigma sustenta as proposições das instituições prisionais, conforme lembra Bianchini (2005), repetindo os preceitos da apropriação do Estado dos corpos daqueles que não se ajustam à ordem social.

Segundo alguns agentes socioeducadores, a socioeducação é "o lugar onde se coloca o lixo da sociedade". Nesse sentido, pensamos como ainda resta muito a ser discutido acerca da função da socioeducação na vida dos jovens e em nosso laço social, cabendonos refletir, inclusive, quais os efeitos do vínculo da socioeducação, em muitos estados brasileiros, à Secretaria de Segurança, Justiça ou Direitos Humanos, e não à Secretaria de Educação.

O que, afinal, é a socioeducação? Como a psicanálise pode se aproximar desse campo? Como o pesquisador-psicanalista pode operar a escuta psicanalítica na socioeducação? De que modo sua posição pode contribuir para a construção de um espaço de fala de agentes socioeducadores? Será que há demanda por parte dos agentes para esse trabalho? Como sustentar a ética psicanalítica onde o traumático ganha destaque? E como fazer essa experiência falar?

Nesse movimento de indagação acerca do fazer do psicanalista em instituições socioeducativas, enunciamos a edificação de um espaço de pesquisa acadêmica que toma a escuta da transferência como alicerce para a sustentação do trabalho de investigação e intervenção em locais com condições precárias. Lançamos, assim, uma narrativa a respeito de uma metodologia de intervenção que se construiu a partir da aproximação da posição do flâneur - retomada por Benjamin a partir dos escritos de Baudelaire - com a ética psicanalítica.

\section{A conjugação da ética da psicanálise com a da flânerie}

Inaugurando a psicanálise como método, Freud (1912a/2006) relaciona a posição do psicanalista com a de um investigador que, através da atenção uniformemente suspensa, não direciona sua libido para nada específico e não emprega qualquer esforço ou seleção ao que é escutado (Freud 1912b/2006). Isso é feito justamente no intuito de poder ajustar a frequência ao que está sendo transmitido em associação livre pelo sujeito que fala, visando recolher o que é emitido desde o inconsciente. Utilizando-se de sua pulsão epistemofílica e pondo-se curioso perante a associação livre do outro, o psicanalista é um pesquisador que intervém justamente enquanto se mantém abstinente quanto ao seu desejo. Nesse sentido, enquanto fazer que é da ordem do impossível, segundo o próprio Freud (1925/2006) indicou, a ética da psicanálise é seu método por excelência (Lacan, 1959-1960/2010), de modo que pesquisa e intervenção coincidem.

Ao usar a atenção flutuante como ferramenta de trabalho, a escuta propicia um playground no qual o sujeito pode apresentar seu inconsciente livremente. Freud (1914/2006) apontava que, nesse entrejogo, as forças repressoras que, por muito tempo, só podem ser expressas em padrões repetitivos, em um a posteriori, engendram novos caminhos de satisfação pulsional a partir de um "novo significado transferencial" (p. 169) que recolheram na transferência. Sendo um pesquisador, como lembra Caon (1997), o psicanalista articula espaços para que o peso do passado e a incerteza do novo possam ser rearranjados em algo potente a partir - e apenas por meio - do seu não-saber. Nesse sentido, promovem-se rupturas nas posições mais colonizadas e colonizadoras.

De modo similar, Benjamin - filósofo das margens que vem inspirando nossos trabalhos há algum tempo - surge, nesta pesquisa, com especial relevo na postura do flâneur, revisitada por ele em vários momentos de sua obra. A flânerie ganha destaque à medida em que, relacionando a posição do flâneur com a do psicanalista, enunciamos a atenção flutuante, preconizada pela psicanálise, e o flâneur, os quais, a partir do que seria descartado ou negado, oferecem um espaço para o tropeço, o impensável e o detalhe - de onde podem se produzir novas formulações acerca das mesmas coisas?

A flânerie de Baudelaire está inserida no sistema, porém resguarda em si certa irregularidade, a qual é expressa naquilo que Benjamin (1937/1989) comparou à posição da prostituta. Rompendo com a indiferença, $o$ flâneur se insere no meio da multidão, sentindo prazer perante as mais tumultuadas vivências em sociedade, à medida que se permite adentrar um espaço de empatia com o próprio lugar da mercadoria, tão valorizada em nossa cultura.

Nessa relação de gozo, que é uma palavra usada pelo próprio Benjamin (1937/1989), a flânerie opera um efeito estético que, ao mesmo tempo, sustenta um ato político de crítica à sociedade. Sua sensibilidade de ver beleza naquilo que já foi usado e está até mesmo em processo de putrefação é a marca da vitalidade da flânerie, que vive com - nem pela sociedade e nem por meio dela - a dimensão do traumático, promovendo um espaço em que os efeitos desse (des)encontro recaiam sobre si.

Ao escutarmos a vivência da violência e do traumático, narrada e apresentada pelos agentes por meio de atos e áridas narrativas, o modo de estar na socioeducação foi se construindo. As ferramentas alçadas pela transferência no percurso da pesquisa levaram a um livre transitar pelos corredores, onde acontecia a escuta do cotidiano dos agentes junto aos adolescentes, aos colegas e à instituição - naquilo que primeiramente nomeamos de

\footnotetext{
7 Salientamos que essas são apenas algumas leituras possíveis das obras de Benjamin, reiterando que falamos de certo lugar e estudamos seus escritos com os limites permitidos por nossa trajetória profissional. São os restos que pudemos recolher em nossa própria flânerie.
} 
Posto Móvel de Escuta ${ }^{8}$. Ao não ocupar o lugar de Outro totalizante, foi possível um espaço (com)Posto ${ }^{9}$, tirando o peso do que é colocado como obrigatório, enrijecido e tradicional, começávamos a fazer deslizar o significante pesquisa na instituição.

A aproximação dos agentes começou a ocorrer de forma bastante orgânica, de modo que logo se percebeu como seria importante circular pela instituição, colocando-se, uma vez na semana, a postos ao lado da entrada da ala, onde os adolescentes e os agentes poderiam ver a pesquisadora. Perguntavam: " $t u$ ainda está ai?", "não vai embora?", "tu voltou por obrigação ou por que gostou?", como em um misto de curiosidade, desvalorização e surpresa perante a pesquisa, que demonstrava se manter na instituição por desejo de oferecer um espaço de fala para eles, e não apenas para colher dados, como diziam alguns agentes.

Acreditamos que, a partir dessa postura de flanar pela instituição, nesse movimento que permitia paradas, se mantinha uma atenção flutuante para algo que surgisse na vivência da pesquisa, sendo, então, possível viabilizar a emergência ${ }^{10}$ de uma demanda de fala dos agentes. Nesse processo, os diários de experiência foram utilizados como ferramenta de registro e de investigação que recorria à metodologia de narrar qualquer coisa que acometesse ao pesquisador a partir de sua vivência, fazendo também referência à influência do trabalho de Benjamin. E, para fazer falar a avalanche de vivências na socioeducação, a fluidez da escrita em associação livre era fundamental para que se descarregassem os emaranhados que se formavam a cada ida à instituição.

Os diários de experiência foram inspirados nos efeitos teórico-metodológicos que decantam da "conjugação e articulação da escuta psicanalítica com o tema da experiência em Walter Benjamin" (Gurski, 2017, p. 48), relembrando os diários de campo utilizados nas pesquisas antropológicas e etnográficas, os breves diários escritos por Freud no final de sua vida e os cadernos de notas confeccionados por Walter Benjamin em sua trajetória de narração acerca de suas memórias e experiências pela cidade.

8 O projeto de qualificação intitulado $A$ construção de um Posto Móvel de Escuta na socioeducação: entre vivências e experiências de agentes socioeducativos (Pires, 2016), trazia o início desta pesquisa e o desenrolar da inspiração da flânerie como metodologia de pesquisa-intervenção. Os caminhos metodológicos percorridos primeiramente pelo ensaio-flânerie tiveram sua sequência na escuta-flânerie.

9 Transitando do imposto para o composto, inspiradas pelo título do trabalho de Gurski, Umpierre e Barros (2013), "Sobre o trabalho com adolescentes das margens em um Posto de Saúde: do (im)POSTO ao (com)POSTO".

10 Brincamos com o significante emergência, pois, entrando na instituição, fizeram-se presentes muitas demandas de emergência (enquanto urgência), de modo que fomos empreendendo uma torção nesses pedidos, imprimindo um espaço para a emergência (que tem origem no verbo emergir) dos sujeitos. À espera dessa emergência, o pesquisadorpsicanalista abre espaço para que conteúdos inconscientes possam vir à tona, desviando-se da lógica mecanicista e promovendo novos direcionamentos da libido.
No a posteriori da escuta dos agentes, algumas vezes, os diários de experiência pareciam impossíveis de serem escritos, tamanha a angústia diante das vivências da pesquisa-intervenção. Mesmo nesses momentos, eles eram interessantes; alguns ficavam mais curtos, outros mais longos, dando espaço para o efeito de narração que se faz presente quando a escrita se dá em flânerie e, em meio aos destroços, se acha alguma espécie de novo. Daí a necessidade de fazer outros diários de experiência, os quais foram se construindo no transcorrer da pesquisa, não apenas referentes a cada ida à instituição socioeducativa, mas escritos que remetiam aos restos que iam ficando pelo caminho e que se reconfiguravam a partir de uma nova escrita. Esses diários maiores traziam fragmentos e perguntas que enunciaram questões importantes, verdadeiros rastros que podiam ser desenvolvidos na escrita final da dissertação ou permanecer inapreensíveis.

\section{Entre vivências e experiências na socioeducação: construindo a escuta-flânerie}

Nas buscas por artigos referentes ao trabalho com agentes socioeducadores no Brasil, encontramos produções esparsas ${ }^{11}$, sendo apenas duas delas voltadas para a pesquisa-intervenção: um trabalho de referencial cognitivo-comportamental com um grupo de socioeducadores (Palma \& Neufeld, 2011) e um relato acerca da produção de uma formação de gestores de centros de socioeducação (Bidarra \& Alapanian, 2013), ambos no Paraná.

Dois outros artigos a que damos destaque aqui são recortes diferentes de uma mesma pesquisa que investigou o nível de estresse nos agentes socioeducadores do Rio Grande do Sul a partir dos aportes da enfermagem (Greco, Magnago, Beck, Urbanetto, \& Prochnow, 2013). Salientando o alto índice de sofrimento psíquico desencadeado pelo trabalho na socioeducação, o estudo aponta para a necessidade de planejamento, por parte dos gestores, de projetos de promoção de saúde dos socioeducadores (Greco, Magnago, Urbanetto, Luz, \& Prochnow, 2015).

Nessa perspectiva, àquela falta de investimento que os agentes socioeducadores enunciavam logo nas primeiras semanas da pesquisa, encontramos correspondência nas produções científicas do país, o que também estava presente no imaginário de alguns colegas e gestores da instituição socioeducativa, que diziam que os agentes não se exporiam e nem falariam. Todavia parece que a sustentação do espaço de escuta e a presença do desejo de escutar o sofrimento do socioeducador em seu fazer possibilitou, na experiência da transferência, a construção de um modo de estar na socioeducação e ali engendrar

11 Acreditamos que outros trabalhos voltados aos agentes socioeducadores possam estar sendo realizados ao redor do Brasil, sem que ainda tenhamos notícias, tendo em vista que a discussão ao redor do tema tem se ampliado. 
algo novo. Respondendo à queixa e à impotência com a instalação do Posto Móvel de Escuta, podemos dizer que a escuta-flânerie despertava em muitos socioeducadores o desejo de falar, aproximando-se desse espaço de diferentes modos, cada um a seu tempo.

A presença e a escuta de um psicanalista pode mobilizar os sujeitos também quando adentra uma instituição, tornando-se foco desse endereçamento que é infiltrado na transferência, recolhendo, em abstinência, o investimento que antes estava destinado a outra coisa, como ao sintoma, por exemplo. Nas palavras de Lacan (1958/1998), a posição de morto do psicanalista corrobora esta sua função de espelho para o desejo do outro. Lacan diz morto não porque está indiferente ou apático, mas porque a posição do psicanalista é de estar presente, sem ser invasivo, estar atento, porém de modo flutuante, dando espaço para que o desejo do outro apareça. Há, portanto, um desejo que deve estar vivo no psicanalista: o de que o sujeito possa advir do encontro com seu inconsciente, ou seja, o desejo de que haja psicanálise!

Nesse sentido, a posição do psicanalista propicia condições para que o sujeito fale, já que é na verdade do inconsciente que aposta, quando escuta em transferência. Tendo isso em mente, Lacan (1959-1960/2010) diferencia a ética da psicanálise da ética da filosofia, desarticulando a vontade de alcançar o Bem Supremo para inaugurar o desejo de fazer falar o inconsciente. O compromisso do psicanalista é, portanto, com o bem-dizer, que está intimamente relacionado à própria coisa ${ }^{12}$, a matéria bruta daquilo que vacila e causa desejo. É, afinal de contas, no cerne da coisa que trabalhamos (Lacan, 1973/2003).

Às narrativas repletas de angústia, que (d) enunciavam ${ }^{13}$ uma total desesperança por parte dos agentes, se somavam a outras linguagens utilizadas por eles. No discurso desses socioeducadores presentificava-se o que é da ordem do traumático, ficando muito marcado o relato de uma hora e trinta minutos de um senhor que contava em detalhes a reforma que foi necessária no prédio de uma das unidades da instituição após um motim, quando um agente foi morto com uma bala no peito. Entendia-se, em meio à angústia do relato, que existe uma reforma interna que cada um dos socioeducadores, que dedicam muitas horas mensais de sua vida à Fundação, deve empreender em nome de sua segurança psíquica. A partir do encontro massivo com o real, como em espelho à reforma do prédio que foi abalado por um motim, "uma casca precisa ser construída", como uma agente enunciou. E isso é vivido na pele também por quem os escuta.

12 A coisa, em psicanálise, faz referência ao que não está no circuito do simbólico. Ver a nota 4 deste artigo, onde articulamos, enquanto conceito, a coisa ao real.

13 Foscarini (2015) adverte que, mais do que denunciar o trabalho na socioeducação, os pesquisadores devem manter a posição de (d)enunciar o outro e a si próprios quanto à implicação ética em relação a essa problemática histórica que a sociedade brasileira carrega.
Os medos e os sentimentos de impotência se faziam presentes na transferência, em tempos mais ou menos regulares da pesquisa-intervenção. Nesses momentos, era fundamental lembrar que, enquanto resistência, conforme apontava Freud (1912a/2006), a transferência busca a repetição do mesmo, mas, enquanto potência, ela serve ao psicanalista como uma direção do caminho a seguir. É na transferência que todo o trabalho se dá, visto que ali estão postas as nuances mais cruas e inusitadas, apresentadas no âmbito do real.

Por muitas vezes, o trabalho era permanecer onde tudo parecia confluir para desistir. A palavra emergia por meio de histórias de morte e de dureza extrema e, noutros momentos, era necessário para eles que mostrassem as instalações, as alas, os banheiros e suas precariedades ou fotos de armas e corpos dilacerados. Esse movimento foi parecendo um meio de testar o quanto a pesquisadorapsicanalista poderia aguentar - em uma espécie de "ritos de passagem". Era como se formulassem uma pergunta sem palavras sobre o desejo da pesquisadora-psicanalista de escutá-los, mesmo nas situações mais adversas, em que talvez não existissem ainda propriamente histórias.

Essa pura apresentação estava também na estética do prédio em que o trabalho foi desenvolvido. Ao alto, a grande escadaria levava a portões enormes de ferro. As paredes largas, as várias passagens para um andar e outro, a depredação do assoalho e a sujeira gritavam por serem escutadas e vistas. Essa noção de apresentação colabora com nosso estudo acerca do traumático e daquilo que não chega a ser a representação de algo, mas se presentifica em nossas vivências como pura quantidade e não pode ser simbolizado ${ }^{14}$.

Na posição do flâneur, daquele que vê potência onde a maioria só vê lixo, daquele que não se apressa quando tudo é pressa, o trabalho imprimia delicadamente um contraponto na própria postura da flânerie. Conforme elucidou um dos diretores, a escuta-flânerie se diferenciava de outros trabalhos e pesquisas que adentravam a instituição sem conseguir ver nada de construtivo feito lá. Em suas palavras, as pesquisas, em geral, concluíam que a socioeducação era uma "terra arrasada". Vivenciando junto aos sujeitos os impactos do encontro com o real, o Posto Móvel de Escuta estava lá dentro, sustentando o interesse de escutar os sujeitos em suas dificuldades e em suas potencialidades, apostando, assim, na emergência de um saber dos socioeducadores.

Nesse ínterim, aponta-se que, assim como a atenção flutuante é emblemática para pensarmos a metodologia da ética da posição do psicanalista, a flânerie seria a contrapartida corporal dessa postura. Ora, o flâneur nada mais é, na proposta que estamos articulando aqui, do que aquele que flutua sobre a materialidade crua e árida da instituição à espera do inconsciente. Assim, a escuta-flânerie comportava certa materialidade necessária

\footnotetext{
14 Para maiores conceitualizações a respeito desses pontos, ver $A$ pesquisa e a intervenção psicanaliticas: transferência, imagem e apresentação na construção da escuta-flânerie (Pires, 2019).
} 
para que a intervenção emergisse na socioeducação, apresentando um tempo distendido e uma curiosidade que montaram a escuta-flânerie como a intervenção per si. Onde havia queixas de desinvestimento e impotência, a simplicidade da flânerie engendrava um contraponto ao fluxo corriqueiro da socioeducação e, na sensibilidade da presença, movimentava-se conforme o ritmo proposto na transferência (Pires, 2018).

Escutando a pressa e a desconfiança que se instauravam na socioeducação a partir de nossa entrada, o circular pelos corredores foi uma forma de trazer certa leveza e poética para a intervenção. Por vezes, a presença da pesquisadora tornava-se invisível, conquistando espaço pouco a pouco junto a cada um dos agentes. Um socioeducador, ao nos encontrar, disse: "tu de novo?!"; "sim" foi a resposta. E ele, dando de ombros, resmunga: "vou ter que falar contigo, então! Fugi todo o tempo antes, agora vou ter que falar", e falou algumas vezes.

$\mathrm{Na}$ insistência da presença, algo se engendrava. Nesse processo, tornou-se primordial o ato analítico de suportar as encenações dos conteúdos mais primitivos dos sujeitos, permitindo que se reproduzissem repetidamente antes mesmo de qualquer possibilidade de narrar e recordar - o que já havia sido apontado por Freud (1914/2006; 1920/2006). Tomando as concepções de Ferenczi (1934/2011) acerca do traumático, trazemos a ideia de que o trauma é uma vivência disruptiva, que promove um dano psíquico e uma dissociação do eu, em que uma parte do sujeito se movimenta subjetivamente e segue vivendo enquanto outra permanece aprisionada ao trauma. Nesse percurso, o que potencializa o peso do traumático é a falta de apoio simbólico do outro, quando nega ou subestima o que o sujeito está sentindo. A incompreensão, a punição e o silêncio daquele que testemunha o trauma ou seus efeitos favorecem a clivagem do eu, que fica abalado e desesperançoso. Isso corrobora a paranoia e a onipotência do sujeito (Ferenczi, 1934/2011).

Kupermann (2008), partindo de Ferenczi, diz que o essencial para trabalharmos com o traumático é que o psicanalista reconheça essa dor, fazendo a função do terceiro que valida e acolhe o sofrimento do sujeito. $\mathrm{Na}$ escuta-flânerie, isso parecia acontecer no simples ato de testemunhar as vivências, quando a pesquisadora as compartilhava na transferência com os socioeducadores. Em outra faixa de intervenção, se reconhecia a atuação do traumático nos sujeitos através das palavras, quando, ao se defrontar com meninos de quinze anos deitados em um chão úmido, enunciou: "isso é o horror do horror!", oferecendo uma continência, um certo contorno ao excesso de real da socioeducação. Nesse sentido, comunga-se do traumático, autorizando o outro e a si mesmo a se deixar afetar pelos impactos da vivência para, a posteriori, catalisar novos movimentos. Entregando-se, portanto, ao sentir com, o psicanalista demonstra reconhecer a percepção do sujeito e a dor psíquica que aqueles acontecimentos provocaram, conforme identifica na transferência (Ferenczi, 1928/2011).

\section{A escuta-flânerie e seus desdobramentos}

Quando a transferência apresentava uma saída à compulsão à repetição, era possível, por exemplo, que a pesquisadora percebesse que não precisava sucumbir ao medo de que houvesse um motim, tendo em vista que já se encontrava com o real por meio da catástrofe encenada e narrada pelos agentes. Nesse trajeto, as pérolas podiam ser recolhidas no meio do caminho, ao passo que as descontinuidades da escuta-flânerie operavam. Afinal, é nas "interrupções neste fluxo do mesmo" (Sousa, 2008, p. 44) que algo novo pode emergir, quando há espaço para a surpresa.

Vemos que a flânerie permite esse outro tempo que não o da correria, do "não se pode perder tempo". O flâneur se propõe a fazer paradas, mudanças de rotas, deixando-se levar livremente pelos encontros e desencontros que sua caminhada proporciona. Essa posição marginal possibilita que se fuja da monotonia e do mecanicismo. Para Benjamin (1982/2009), a flânerie escancarava, em seu próprio modo de se apresentar ao mundo, "sua simples e íntima proximidade" (p. 461) com as ruínas de seu tempo. Colocando em curso um ato, em que se fazia referência a certa narratividade histórica, a flânerie se configurou como uma intervenção social que prestava um testemunho ao que havia sido vivenciado. Assim, a flânerie se transformou em uma intervenção que enaltece o inusitado.

O dispositivo dos diários de experiência e a inspiração na flânerie, tecidos ao longo de anos de pesquisa, foram fundamentais para que as vivências na instituição socioeducativa pudessem se transformar em experiências a partir da posição ética da psicanálise na pesquisa-intervenção. O tempo do a posteriori, a escrita dos diários e a premissa de não nos anteciparmos à experiência (Gurski, 2014) construiu as condições necessárias para que este trabalho fosse nomeado de escuta-flânerie. Foi no desenrolar do tempo que as escritas dos diários puderam se transformar em construções para o campo da pesquisa em psicanálise. Esse tempo do só-depois mostra que o efeito da experiência da transferência operou em todos, de modo que não se sabe o que veio antes, o inconsciente ou a disponibilidade de alguém escutá-lo.

O pesquisador-psicanalista encontra o inconsciente, deixando-se levar pelas vivências; como disse Lacan (1963-64/2008) inspirando-se em Picasso, "eu não procuro, eu acho" ${ }^{15}$ (p. 14). Assim, elucidamos a criação de um espaço de escuta em que a palavra dita em transferência possibilita ao sujeito articular pequenas brechas em seu discurso, deixando vir à tona seu inconsciente e, naquilo que parece uma repetição do mesmo, encontra-se o que não se procurava. Emerge, nessa narrativa, uma pérola, um deslizamento, um questionamento, uma ação.

15 Para comentários sobre este paralelo, ver Gurski (2014). 
Entrando em uma instituição socioeducativa, foi imprescindível brincar com a dimensão mortífera das vivências apresentadas e faladas pelos sujeitos. Como modo de acessá-los, foi necessário passear pelo caos, mantendo o lugar do estranho e do estrangeiro, que se surpreende e recolhe os pontos extraviados das narrativas e das cenas-imagens por meio de sua atenção flutuante e sua flânerie. Em uma espécie de testemunho, construído a partir da experiência de transferência, em que o traumático tem livre curso, mas também mantém a posição de alteridade, foi possível abrir caminhos para achar, sem procurar, o inconsciente dos sujeitos e seu desejo de falar. Em outras palavras, configurou-se a presença da pesquisadora-psicanalista-flâneur como intervenção. E, nesse aspecto, a transferência era a via simbólica fundamental ao trabalho, desde que os socioeducadores pudessem iniciar um processo de simbolizar esse símbolo, como apontava Lacan (2016), ou, como diríamos, mobilizar uma transferência com esse lugar de escuta e, assim, se pôr a falar.

De todo modo, alguns agentes nunca falaram com a pesquisadora, o que, de qualquer forma, nunca fora nosso intuito, tendo em vista que não almejávamos uma pesquisa totalizadora. Nesse sentido, precisamos ser humildes e dizer que a socioeducação funciona, ainda que se possam articular críticas quanto à forma como ela acontece. A escuta-flânerie não salva almas nem se propõe a isso. Ela arma pequenos espaços para que deslocamentos sutis, mas importantes, sejam possíveis. E, nesse contexto, a escuta-flânerie retoma todos os trabalhos que temos desenvolvido no grupo. A psicanálise, sendo chamada a dizer algo sobre as instituições sociais, tem se mostrado extremamente revigorante, desde que possa trabalhar na transferência e se inserir com delicadeza nos locais por onde circula e é demandada, mantendo a ética do sujeito e do desejo em sua temporalidade própria. Dizemos, por fim, que a escuta-flânerie é um modo de pesquisar psicanaliticamente na instituição socioeducativa, que poderá fazer mais ou menos sentido para o pesquisadorpsicanalista, conforme suas inspirações, leituras e experiências.

A partir da extrema escassez de desvios e contornos para o real do trabalho realizado, sustentamos que uma parcela da intervenção se dava na flânerie enquanto presença e posição destoante que, por si só, exercia um efeito de surpresa e desarranjo. Mais adiante, a flânerie passou a ser a ferramenta pela qual alguns agentes se punham a falar. Dessa forma, a palavra operava como potencialidade criativa, mote de uma expressão transferencial já cunhada por Freud e desenvolvida em Lacan. Os agentes vivenciavam, por entre rastros, a escuta-flânerie na sua ética do bem-dizer e do tempo distendido, construindo e montando, entre fragmentos, algumas questões acerca do seu fazer.

Pensamos que a pesquisa-psicanalítica nesses sítios se enlaça com a possibilidade de que haja efeitos de sujeito - instantes em que este depara com o novo e com a emergência da libido ali, onde tudo parecia cristalizado num mesmo sistema de significantes. A partir de uma narrativa, escutada em transferência desde a ética psicanalítica, os restos podem adquirir estatuto de valor para o sujeito, provocando, assim, novos movimentos naquilo que estava sendo construído como certeza. Um processo que acontece na delicadeza do mínimo detalhe e que não reserva para si qualquer compromisso com uma mudança subjetiva do sujeito na vida, disponibilizando um espaço para que pequenos rastros do desejo eclodam, deixando emergir a verdade do sujeito. Nesse aspecto, os socioeducadores, ao narrarem acontecimentos e sentimentos, escutavam um saber que já estava com eles, porém sem uma nomeação ou, estando nomeado, não lhes parecia ter qualquer valor.

Em certa passagem, uma agente leva três adolescentes para a sala da chefia, grita com eles e sai muito brava. Vendo-a sair pelo corredor e entrando noutra sala, a pesquisadora vai ao seu encontro e pergunta se ela quer falar. A agente, que assistia à televisão, diz que pode ser bom, levantando-se e indo até outra sala, onde fala que está tremendo de tanta raiva. Diz que os guris estão muito confiantes e narra o que aconteceu durante o pátio. "Infelizmente, às vezes eles só entendem grito, não dá para falar baixinho", enuncia, falando que ficou com muita raiva e que é raro acontecer isso. Não teve apoio dos colegas, "ninguém faz nada", diz. A pesquisadora-psicanalista então aponta que, na verdade, muitas coisas a irritaram. A agente afirma que os guris estão se aproveitando do caos e diz, surpreendendo a si mesma e à pesquisadora: "na verdade, parece que os colegas estão querendo que dê alguma coisa ruim. . . na real é isso, porque daí a direção vai ter que se explicar".

Pensando que ela denuncia algo fundamental, a pesquisadora-psicanalista não a interrompe, e ela segue:

Sabe o que vou fazer? Vou aproveitar que tenho que pegar essa assinatura e vou ali à direção pedir uma revista, faz tempo que não tem! Os guris devem ter alguma coisa guardada! Aqui é assim: quando eles estão muito confiantes tem coisa... quando eles estão muito quietos a gente diz: quietos até demais!

Quando compartilhado o sentimento de raiva, nessa passagem que se deu da televisão à direção, a narrativa da socioeducadora trouxe a questão de como os agentes fabricam situações de perigo com uma segurança falha, colocando em risco a vida de todos. Além disso, a socioeducadora aponta para um mecanismo do qual os agentes podem lançar mão no intuito de se fazer ver, chamando atenção da direção e da sociedade para o que vivenciam na socioeducação. Enunciando isso, naquele momento, rompe com as identificações em torno do tema do abandono, possibilitando montar uma nova posição para seu trabalho naquele momento. Dando outro nome para o mal-estar que a acometia, a raiva destinada aos jovens deslizou para os colegas e, assim, a socioeducadora 
desativou um lugar de apagamento, não cedendo de seu desejo de estar mais próxima do socioeducar e de um saber próprio acerca do comportamento dos adolescentes.

\section{Sobre alguns restos e rastros}

Ao chegar à instituição socioeducativa, com os ritmos e compassos das vivências somados às construções metodológicas que já vínhamos construindo ao longo de outras investigações, criou-se, junto ao campo, a escutaflânerie como intervenção, traçando uma possibilidade de aproximação entre a pesquisa psicanalítica e a socioeducação. À medida que o Posto Móvel de Escuta transitava - inclusive em suas paradas -, decantava para nós a relevância de também discutirmos a função do socioeducador, sendo fundamental a existência de espaços coletivos em que os agentes pudessem narrar e compartilhar experiências, reconhecendo os saberes construídos acerca do socioeducar ${ }^{16}$.

Neste artigo, entretanto, focamos em ressaltar como as apresentações e as narrativas dos agentes foram emergindo em meio ao livre circular pela instituição socioeducativa, costuradas pela conjugação da psicanálise com os efeitos ético-metodológicos da flânerie. $\mathrm{Na}$ radicalidade da experiência da pesquisa psicanalítica na socioeducação, precisávamos, de tempos em tempos, retornar aos pressupostos da metodologia da escutaflânerie, revalidando a potência da narração e do compartilhamento. De modo orgânico, foi se constituindo a reunião de dois ou mais socioeducadores que falavam informalmente de questões de seu fazer nos corredores da instituição. Algo novo surgia, engendrando, em ato, um contraponto ao sentimento de solidão, tão profundamente infiltrado nos agentes.

Mais amplamente, uma de nossas expectativas a partir deste trabalho é de que alguns rastros aqui deixados inspirem outros pesquisadores a se aproximarem da socioeducação. Em meio a construções metodológicas anteriores (Gurski, 2008, 2014; Gurski \& Strzykalski, 2018) acerca da flânerie como inspiração para a pesquisa psicanalítica, a experiência desta pesquisa-intervenção foi uma aposta em outros possíveis modos de a psicanálise estar em instituições sociais como a socioeducativa. A partir dos diferentes espaços de compartilhamento da experiência, em especial na orientação, a escutaflânerie surgiu como um efeito da conjugação da escuta psicanalítica com a ética do flâneur. Nesse sentido, sustentamos que este trabalho marca, com a estética da escuta-flânerie, a potência e a ousadia da ética psicanalítica em tempos sombrios - pelo menos nos fugazes momentos em que o diapasão do inconsciente se abria na experiência com os socioeducadores.

\title{
The creation of listening-flânerie: a psychoanalytic study with socioeducators
}

\begin{abstract}
The creation of circles for conversation between cautious teenagers of a socio-educational institution promoted by the respective Research Center of this study allowed us to widen the spaces of listening to socioeducators. The massive presentation of reality using the location aesthetics, the scenes witnessed in the institution and narratives provided by these actors was based on two theoretical assumptions: psychoanalytic listening and Benjamin's reading of Baudelaire's flâneur position. The flâneur, as the one who imprints a distended time into urgency, was considered the physical correspondent for floating attention. Psychoanalysis and flânerie were combined to free spaces for narration, through which educators could revisit lost points of social history and their own history. Lastly, this text presents listening-flânerie as another way for listening and psychoanalytic research to be present in such scenarios.
\end{abstract}

Keywords: psychoanalytic research, socioeducators, socioeducation, listening-flânerie.

\section{La construction de l'écoute-flânerie: une recherche psychanalytique avec des socioéducateurs}

Résumé : Dès les Roues de Conversation avec les adolescents pris en charge dans un établissement socio-éducatif, développé par le Centre de recherche dans lequel cette recherche est insérée, nous avons décidé d'élargir les espaces d'écoute des agents socio-éducateurs. La présentation massive de la réalité, à travers l'esthétique du lieu, les scènes observées dans l'institution et quelques récits des agents, a été engendrée par deux présupposés théoriques : l'écoute psychanalytique et la lecture par Benjamin de la position du flâneur baudelairien. Le flâneur, comme celui qui imprime un temps distendu à l'urgence, a été pris comme correspondant corporel pour l'attention flottante. En ce sens, la psychanalyse et la flânerie ont été conjuguées afin d'ouvrir des espaces de narration, à travers lesquels les sujets pourraient reprendre des points perdus de l'histoire sociale et des leurs propres histoires. L'écriture présente l'écoute-flânerie comme un moyen pour l'écoute et la recherche psychanalytique être aussi présent dans ces sites.

Mots-clés : recherche psychanalytique, socio-éducateurs, socio-éducation, écoute-flânerie.

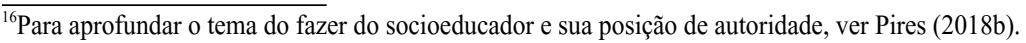




\section{La construcción de la escucha-flânerie: una investigación psicoanalítica con socioeducadores}

Resumen: A partir de rondas de conversación con adolescentes acautelados en una institución socioeducativa, desarrolladas por el Núcleo de Investigación en el cual se inserta esta investigación, decidimos ampliar los espacios de escucha a los agentes socioeducadores. La presentación masiva del real mediante la estética del lugar de las escenas presenciadas en la institución y de algunas narrativas de los agentes fueron manejadas a partir de dos presupuestos teóricos: la escucha psicoanalítica y la lectura benjaminiana de la posición del flâneur de Baudelaire. El flâneur, como el que imprime un tiempo distendido a la urgencia, se tomó como el correspondiente corporal para la atención flotante. En este sentido, el psicoanálisis y la flânerie se conjugaron a fin de abrir espacios de narración, a través de los cuales los sujetos pueden retomar puntos extraviados de la historia social y de su propia historia. El texto presenta la escucha-flânerie como un modo de que la escucha y la investigación psicoanalítica están presentes también en estos sitios.

Palabras clave: investigación psicoanalítica, agentes socioeducadores, socioeducación, escucha-flânerie.

\section{Referências}

Arendt, H. (1987). Homens em tempos sombrios. São Paulo, SP: Companhia das Letras. (Trabalho original publicado em 1955)

Benjamin, W. (1989). O Flâneur. In W. Benjamin, Charles Baudelaire: um lírico no auge do capitalismo - obras escolhidas III (pp. 37-68). São Paulo, SP: Brasiliense. (Trabalho original publicado em 1937)

Benjamin, W. (2009). Passagens. São Paulo, SP: Brasiliense. (Trabalho original publicado em 1982)

Benjamin, W. (2012). Experiência e pobreza. In W. Benjamin, Magia e técnica, arte e politica: ensaios sobre literatura e histórias da cultura - obras escolhidas I (pp. 123-128). São Paulo, SP: Brasiliense. (Trabalho original publicado em 1933)

Bianchini, E. N. (2005). Doutrinas do direito da criança e do adolescente. Recuperado de http://bit.ly/39vNyQY

Bidarra, Z. S., \& Alapanian, S. (2013). Contribuição à construção da dimensão político-pedagógica da socioeducação e à formação de socioeducadores. Revista Brasileira Adolescência e Conflitualidade, (7), 6-20.

Brasil. (2006). Presidência da República. Secretaria Especial dos Direitos Humanos da Presidência da República. Sinase: Sistema Nacional de Atendimento Socioeducativo. Brasília, DF: Conanda.

Brasil. (2014). Secretaria de Direitos Humanos da Presidência da República. Governo do Estado do Rio Grande do Sul. Secretaria da Justiça e dos Direitos Humanos. Fundação de Atendimento Socioeducativo do Rio Grande do Sul. PEMSEIS: Programa de Execução de Medidas Socioeducativas de Internação e Semiliberdade do Rio Grande do Sul. Porto Alegre, RS: SDH.

Brasil. (2015). Estatuto da criança e do adolescente (13a ed.). Brasília, DF: Câmara dos Deputados.

Caon, J. L. (1997). Serendipidade e situação psicanalítica de pesquisa no contexto da apresentação psicanalítica de pacientes. Psicologia: Reflexão e Crítica, 10(1), 105123. Recuperado de http://bit.ly/2Tjkl6k

Ferenczi, S. (2011). Elasticidade da técnica psicanalítica. In S. Ferenczi, Obras completas (Vol. 4, pp. 29-42). São Paulo, SP: Martins Fontes. (Trabalho original publicado em 1928)
Ferenczi, S. (2011). Reflexões sobre o trauma. In S. Ferenczi, Obras completas (Vol. 4, pp. 125-135). São Paulo, SP: Martins Fontes. (Trabalho original publicado em 1934)

Foscarini, L. T. (2015). Quando as violações ocorrem em nome da proteção: apontamentos sobre o uso abusivo de medicação nas unidades de internação de adolescentes da Fase/RS. In A. P. M. Costa, \& D. D. Eilberg (Orgs.), Justiça juvenil na contemporaneidade (pp. 45-52). Porto Alegre, RS: DM.

Freud, S. (2006). A dinâmica da transferência. In Edição standard brasileira das obras psicológicas completas de Sigmund Freud (J. Salomão, trad., Vol. 12, pp. 109-119). Rio de Janeiro, RJ: Imago. (Trabalho original publicado em 1912a)

Freud, S. (2006). Recomendações aos médicos que exercem a psicanálise. In Edição standard brasileira das obras psicológicas completas de Sigmund Freud (J. Salomão, trad., Vol. 12, pp. 123-158). Rio de Janeiro, RJ: Imago. (Trabalho original publicado em 1912b)

Freud, S. (2006). Recordar, repetir e elaborar. In Edição standard brasileira das obras psicológicas completas de Sigmund Freud (J. Salomão, trad., Vol. 12, pp. 162-171). Rio de Janeiro, RJ: Imago. (Trabalho original publicado em 1914)

Freud, S. (2006). Além do princípio do prazer. In Edição standard brasileira das obras psicológicas completas de Sigmund Freud (J. Salomão, trad., Vol. 23, pp. 13-75). Rio de Janeiro, RJ: Imago. (Trabalho original publicado em 1920)

Freud, S. (2006). Prefácio à "Juventude desorientada", de Aichhorn. In Edição standard brasileira das obras psicológicas completas de Sigmund Freud (J. Salomão, trad., Vol. 19, pp. 305-308). Rio de Janeiro, RJ: Imago. (Trabalho original publicado em 1925)

Fundação de Atendimento Socioeducativo do Rio Grande do Sul. (2015). Relatório técnico de Atividades da Fundação de Atendimento Socioeducativo. Recuperado de http://bit.ly/2x7W62r

Greco, P. B. T., Magnago, T. S. B. S., Beck, C. L. C., Urbanetto, J. S., \& Prochnow, A. (2013). Estresse no trabalho em agentes dos centros de atendimento socioeducativo do Rio Grande do Sul. Revista Gaúcha 
de Enfermagem, 34(1), 94-103. doi: 10.1590/S198314472013000100012

Greco, P. B. T., Magnago, T. S. B. D. S., Urbanetto, J. D. S., Luz, E. M. F. D., \& Prochnow, A. (2015). Prevalência de distúrbios psíquicos menores em agentes socioeducadores do Rio Grande do Sul. Revista Brasileira de Enfermagem, 68(1), 93-101. doi: 10.1590/0034$7167.2015680113 \mathrm{p}$

Gurski, R. (2008). Juventude e paixão pelo real: problematizações sobre experiência e transmissão no laço social atual (Tese doutorado). Universidade Federal do Rio Grande do Sul, Porto Alegre, RS.

Gurski, R. (2012). Três ensaios sobre juventude e violência. São Paulo, SP: Escuta.

Gurski, R. (2014). Três tópicos para pensar (a contrapelo) o mal na educação. In R. Voltolini, R. (Org.), Retratos do mal-estar na educação contemporânea (pp. 25-45). São Paulo, SP: Escuta.

Gurski, R. (2017). A escuta de jovens "infratores", o rap e o poetar: deslizamentos da vida nua à vida "loka". Revista subjetividades, 17, 45-56.

Gurski, R., \& Strzykalski, S. (2018). A pesquisa em psicanálise e o catador de restos: enlaces metodológicos. Ágora, 21, 406-415.

Gurski, R.; Umpierre, A., \& Barros, J. (2013). Sobre o trabalho com adolescentes das margens em um Posto de Saúde: do (im)POSTO ao (com)POSTO. In Infância, educacion, derechos de ninos, ninas e adolescentes: las praticas profissionales en los limites de la experiência $y$ del saber disciplinar, 4. Simpósio apresentado na Universidad de Mar del Plata, Mar del Plata.

Kupermann, D. (2008). Presença sensível: cuidado e criação na clínica psicanalítica. Rio de Janeiro, RJ: Civilização Brasileira.

Lacan, J. (1998). A direção do tratamento e os princípios do seu poder. In Escritos (pp. 591-652). Rio de Janeiro, RJ: Jorge Zahar. (Trabalho original publicado em 1958)

Lacan, Jacques. (2003). Televisão. In Outros escritos (pp. 508-543). Rio de Janeiro, RJ: Jorge Zahar. (Trabalho original publicado em 1973)

Lacan, J. (2008). O seminário, livro 11: os quatro conceitos fundamentais da psicanálise. Rio de Janeiro, RJ: Jorge Zahar. (Trabalho original publicado em 1963-64).
Lacan, J. (2010). O seminário, livro 7: a ética da psicanálise. Rio de Janeiro, RJ: Jorge Zahar. (Trabalho original publicado em 1959-1960)

Lacan, J. (2016). O simbólico, o imaginário e o real. Conferência apresentada em 8 de julho de 1953 na Sociedade Francesa de Psicanálise. Recuperado de http://bit.ly/2VI4G1R

Palma, P. C., \& Neufeld, C. B. (2011). Intervenção cognitivocomportamental em grupo de socioeducadores: um relato de experiência. Revista Brasileira de Terapias Cognitivas, 7(1), 55-61.

Pires, L. (2016). A construção de um Posto Móvel de Escuta na socioeducação: entre vivências e experiências de agentes socioeducativos (projeto de mestrado). Universidade Federal do Rio Grande do Sul, Porto Alegre, RS.

Pires, L. P. (2018a). A construção da escuta-flânerie: uma pesquisa psicanalítica com agentes socioeducadores que atendem adolescentes em conflito com a lei (dissertação de mestrado). Universidade Federal do Rio Grande do Sul, Porto Alegre, RS.

Pires, L. P. (2018b). A função do (socio)educador de adolescente: a autoridade do desejo. In C. Chazan, \& L. Só (Org.), Vida adolescente: perspectivas de compreensão (pp. 111-127). Porto Alegre, RS: Editora Fi.

Pires. L. P. (2019). A pesquisa e a intervenção psicanalíticas: transferência, imagem e apresentação na construção da escuta-flânerie. In R. T. Souza, M. S. Mattos, H. Ribeiro, T. S. Rodrigues, E. Pontel, B. O. Bortolini . . . G. N. Souza (Org.), Walter Benjamin: estética, política, literatura, psicanálise (pp. 631-649). Porto Alegre, RS: Editora Fi.

Sousa, E. L. A. (2008). A burocratização do amanhã: utopia e ato criativo. Porto Arte, 14(24), 41-51. doi: 10.22456/2179-8001.27933

Vidal, A. S., Vidal, A., Pamplona, R., Luchese, S., Szuchman, K., Santos, M. C., . . Giuliani, E. M. (2015). Reformas legislativas no âmbito do direito penal juvenil: o adolescente como inimigo. In A. P. M. Costa, \& D. D. Eilberg (Orgs.), Justiça juvenil na contemporaneidade (pp. 37-43). Porto Alegre, RS: DM.

Recebido: 02/07/2018 Aprovado: 08/11/2019 